\title{
PENERAPAN ALAT PENGERING RENGGINANG DI DESA TIRTOMARTO KECAMATAN AMPELGADING KABUPATEN MALANG
}

\author{
Erni Junita Sinaga $^{1)}$, Anis Artiyani ${ }^{2)}$, Erni Yulianti ${ }^{3)}$, Harimbi Setyawati ${ }^{4)}$ \\ ${ }^{1)}$ Program Studi Teknik Industri, Institut Teknologi Nasional Malang \\ 2) Program Studi Teknik Lingkungan, Institut Teknologi Nasional Malang \\ ${ }^{3)}$ Program Studi Teknik Sipil, Institut Teknologi Nasional Malang \\ 4) Program Studi Teknik Kimia, Institut Teknologi Nasional Malang \\ erni junita@lecturer.itn.ac.id
}

\begin{abstract}
Abstrak. Proses pengeringan kerupuk rengginang pada UKM olahan makanan di Desa Tirtomarto Kecamatan Ampelgading Malang masih tradisional yaitu dengan menggunakan sinar matahari. Hal tersebut menyebabkan proses pengeringan menjadi tidak optimal karena membutuhkan waktu yang lama 8-10 jam karena tempat pengeringan yang luas, dan rendahnya higienitas produk.

Tahapan pembuatan alat pengering makanan menggunakan metode ergonomi yaitu dengan penerapan antropometri pengguna yang kemudian diuji keseragaman dan kecukupan datanya. Selanjutnya dilakukan analisa terhadap proses kerja karyawan saat pengeringan rengginang dan melakukan perhitungan waktu standart serta output standart kerja yang sudah ada saat ini.

Hasil penelitian diperoleh adanya peningkatan waktu standart,yang semula dengan cara sederhana waktu standart (Ws) yang dihasilkan sebesar 487,13 menit atau 8,11 jam sedangkan dengan menggunakan alat pengering yang baru waktu standart (Ws) yang diperoleh sebesar 23,56 menit. Untuk output standart (Os) proses pengeringan yang lama hanya menghasilkan $0,102 \mathrm{~kg} /$ jam sedangkan menggunakan alat baru sebesar $2,1 \mathrm{~kg} /$ jam ( Terjadi peningkatan ouput sebesar 95,14\% ).
\end{abstract}

Kata Kunci : alat pengering, proses pengeringan

\section{PENDAHULUAN}

Pada Sentra Rengginang yang berada di Desa Tirtomarto, Kecamatan Ampelgading Malang merupakan UKM yang bergerak dalam bidang olahan makanan ini juga menjadi dampak dari perkembangan teknologi yang pesat, UKM ini memproduksi olahan makanan yaitu rengginang yang merupakan cemilan khas orang Jawa. Dalam proses produksinya, UKM ini setiap harinya mampu mengolah sebanyak 100 kilogram beras ketan tiap hari dengan proses produksi yang masih sangat sederhana. Ini menyebabkan kurang maksimalnya proses produksi. Disamping itu, proses produksi menjadi tidak efektif karena dalam proses pembuatanya masih mengandalkan kebaikan alam untuk proses pengeringannya, kendala yang dialami juga datang dari segi kenyamanan kerja yang kurang diperhatikan sehingga menjadikan kinerja dari para pekerjanya tidak maksimal. Proses itu terlihat pada proses penjemuran rengginang, terlihat posisi kerja yang tidak nyaman ini dapat menjadi hambatan yang signifikan saat proses produksi berlangsung.
Selain itu, kendala dalam hal peningkatan produksi yang lainnya ialah pada saat proses pengeringan, karena dalam hal ini masih mengandalkan sinar matahari. Sehingga ketergantungan pada kondisi iklim saat pengeringan, menjadikan persoalan tersendiri. Ini mengakibatkan tidak bisa mengoptimalkan kapasitas produksi, karena proses pengeringan tergantung pada intensitas cahaya matahari, yang memerlukan tempat yang sangat luas. Selain itu, higienis produk juga menjadi faktor yang tidak diperhatikan. Selama ini, proses penurunan kadar air rengginang dilakukan dengan menjemur di bawah sinar matahari selama lebih kurang 1-2 hari. Proses pengeringan secara konvensional yang dilakukan memiliki beberapa kelemahan yaitu rendahnya higienitas produk, konsumsi waktu pengeringan dan intensitas matahari yang tidak merata sepanjang hari. Hal ini mempengaruhi proses produksi yang menurunkan kualitas produk.

Salah satu penyebab kerusakan bahan dan produk agro industri adalah kerusakan mikrobiologis. Kerusakan ini disebabkan karena 
banyaknya sumber energi yang terkandung dalam bahan pertanian, seperti protein dan karbohidrat. Kedua sumber energi ini yang memicu tumbuhnya mikroba. Selain itu faktor kandungan air yang terkandung dalam bahan juga salah satu keadaan yang disukai oleh mikroorganisme. Adapun cara pengeringan yang lebih higienis dan efektif dengan menggunakan mesin pengering.

Alat pengering dapat dikelompokkan menjadi 2, berdasarkan jenis bahan yang dikeringkan, yaitu pengering bahan padat dan pasta, seperti pengering rak, pengering konveyor, pengering rotary, pengering flash, pengering beku, dan pengering fluidized bed, pengering bahan cair, seperti spray dryer dan drum dryer.

Proses pengeringan rengginang saat ini yang ada pada UKM masih kurang nyaman dan masih mengandalkan sinar matahari dan tentunya membutuhkan waktu yang sangat lama begitu juga dengan tenaga yang harus dikeluarkan untuk melihat kondisi rengginang yang sudah kering maupun yang belum kering, sehingga menjadi kurang optimalnya proses produksi.Permasalahan secara terperinci dapat dijabarkan sebagai berikut:

1. Proses pengeringan membutuhkan waktu yang cukup lama karena masih mengandalkan sinar matahari, maka dibutuhkan alat yang mampu menggantikan proses pengeringan menggunakan sinar matahari.

2. Beban kerja pada saat penyusunan rengginang basah ke wadah bambu sangat tidak mengguntungkan, beban kerja diakibatkan oleh sikap kerja yang tidak ergonomic.

3. Pada proses produksi, banyak beban kelelahan yang seharusnya dapat diminimalisir sehingga proses produksi dapat lebih efektif dan mengurangi kelelahan kerja.

\section{METODE}

Metodologi penelitian secara operasional merupakan cara yang dilakukan untuk mendapatkan data maupun informasi yang berhubungan dengan yang masih diteliti. Langkah-langkah penelitian yang dilakukan sebelum perancangan alat pengering makanan yang ergonomis adalah :

1. Melakukan survey lapangan untuk mengamati proses produksi yang ada saat ini.
2. Melakukan pengumpulan dan pengolahan data waktu untuk digunakan sebagai penunjang untuk menganalisa waktu, ukuran, dan posisi gerak tubuh, yang dilakukan oleh operator saat melakukan aktifitas kerja langsung dengan alat lama atau alat yang sudah ada untuk saat ini.

3. Melakukan pengumpulan dan pengolahan data antrophometri yang diambil dari dimensi tubuh orang dewasa, yang nantinya akan dipergunakan dalam penyusunan tabel antrophometri beserta analisa keseragaman data dan kecukupan data.

4. Melakukan analisa terhadap proses kerja pengeringan rengginang yang sudah ada pada saat ini.

5. Melakukan perhitungan waktu standart dan output standart kerja.

6. Melakukan perancangan sistem kerja mesin pengering rengginang

\section{HASIL DAN PEMBAHASAN}

Data antropometri digunakan sebagai acuan dalam perancangan produk yang ergonomis. Pentingnya penentuan anthropometri pengguna produk adalah untuk menyesuaikan dimensi atau ukuran tubuh pengguna produk tersebut dengan desain produk, sehingga dapat memberikan kenyamanan, keamanan dan keleluasaan dalam beraktifitas. Berikut ini data-data anthropometri tidak lepas dari faktor persentil dan faktor penyesuaian. Dan anthropometri yang digunakan dalam penelitian ini, adalah :

\section{Tinggi mata saat berdiri}

Definisi : $\quad$ Tinggi mata saat berdiri adalah jarak vertikal dari kaki bagian bawah hingga mata yang mengarah lurus kedepan.

Penerapan: Pengukuran ini bermanfaat dalam penepatan tinggi maksimum untuk jangkauan kerja dalam proses mengatur suhu mesin pegering. Persentil $50 \%$ digunakan agar lebih nyaman digunakan karena sebagian operator memiliki ukuran yang hampir sama.Ukuran yang digunakan $=146 \mathrm{~cm}$.

\section{Jarak dari siku kanan ke siku kiri}

Definisi :Jarak siku kanan ke siku kiri adalah jarak horisontal maksimal antara lebar dari ujung dalam siku kanan ke siku kiri.

Penerapan :Untuk menentukan lebar loyang yang akan digunakan sebagai wadah makanan yang akan dikeringkan. Persentil yang digunakan $50 \%$. Ukuran yang digunakan $=34 \mathrm{~cm}$. 


\section{Jangkauan Tangan kedepan}

Definisi : Jangkauan tangan kedepan adalah jarak horisonal maksimum yang diambil dari bahu hingga ujung jari yang paling panjang. Penerapan: Data ini sangat penting dalam menentukan kedalaman dari mesin pengering ini. Persentil yang digunakan 50\%.Ukuran yang digunakan $=66 \mathrm{~cm}$

\section{Tinggi siku saat berdiri}

Definisi : Tinggi siku saat berdiri adalah jarak vertikal maksimal dari kaki menuju siku.

Penerapan : Data ini untuk menentukan handle mesin. Persentil yang digunakan $50 \%$. Ukuran yang digunakan $=99 \mathrm{~cm}$.

\section{Jangkauan tangan kesamping}

Definisi : Jangkauan tangan kesamping adalah jarak horisontal maksimum yang didapat dari bahu menuju ujung jari yang paling panjang.

Penerapan : Pengukuran ini bermanfaat dalam menentukan lebar pintu yang nantinya akan digunakan dalam mesin pengering ini. Persentil yang digunakan $50 \%$. Ukuran yang digunakan $=$ $68 \mathrm{~cm}$.

\section{Jongkok}

Definisi : Jongkok adalah jarak vertikal yang diambil dari kaki bagian bawah sampai menuju bahu

Penerapan :Data ini digunakan dalam menentukan tinggi wadah kompor yang akan digunakan untuk menaruh kompor. Persentil yang digunakan $50 \%$. Ukuran yang digunakan $=$ $87 \mathrm{~cm}$

\section{Kriteria Desain}

Berdasarkan penelitian maka konsep yang dijadikan acuan untuk mendesain mesin pengering makanan adalah :

1. Mekanisme Mudah
Mesin pengering ini dapat dipahami cara kerja dan cara pengoperasiannya

2. Perawatan Mudah

Alat yang dirancang perawatannya mudah karena bahan yang digunakan dari bahan yang mudah untuk dibersihkan serta yang digunakan memungkinkan alat tersebut dalam keadaan bersih.

3. Kualitas Terjamin

Daya tahan atau kekuatan dari mesin pengering makanan bisa terjaga dengan keadaan baik karena dari bahan yang kuat.

Spesifikasi Teknis Mesin Pengering Makanan

Mesin pengering makanan ini memiliki spesifikasi seperti ini:

- Kapasitas : 4 rak / loyang

Setiap 1 rak memiliki ukuran 40 x $40 \mathrm{~cm}$ yang muat sekitar 40 biji rengginang dengan diameter rengginang $4 \mathrm{~cm}$

- Dimensi : 70 x 66 x $147 \mathrm{~cm}$

Ukuran tersebut telah disesuaikan dengan data antropometri yang sudah dihitung sebelumnya.

- Bahan : Stainless Stell, Besi

Bahan - bahan ini digunakan karena memiliki sifat penghantar panas yang baik dan lebih tahan lama dari pada material bahan yang lainnya

- Blower

Blower digunakan sebagai penyebaran panas yang didapat dari kompor pemanas kemudian disebarkan oleh blower melalui celah - celah kecil yang terdapat pada mesin

- $\quad$ Sumber panas : Gas LPG

Gas LPG dipilih karena harga yang terjangkau, mudah dicari serta dapat menimbulkan panas yang kostan.

Tabel 1. Perbandingan Alat Lama dan Alat Baru

\begin{tabular}{lll}
\hline Uraian & Alat Lama & Alat Baru \\
\hline Posisi Kerja & Membungkuk & Berdiri \\
\hline Waktu & 10,4 jam & 28,4 menit \\
\hline Output & $0,102 \mathrm{~kg} / \mathrm{jam}$ & $2,1 \mathrm{~kg} / \mathrm{jam}$ \\
\hline Sumber pengeringan & Sinar matahari & Gas \\
\hline Efisiensi Waktu & Kurang Efisien & Efisien \\
\hline Efisiensi Tenaga & Kurang Efisien & Efisien \\
\hline
\end{tabular}




\section{KESIMPULAN}

Dari hasil kegiatan penelitian yang telah dilaksanakan dapat diambil kesimpulan :

1. Mesin Pengering Rengginang adalah mesin yang sangat dibutuhkan dalam proses produksi agar lebih efektif dan efisien.

2. Mesin Penggering Rengginang ini juga irit bahan bakar.

3. Penggunaan mesin Pengering Rengginang ini dapat mengurangi rasa lelah yang ditimbulkan.

4. Keefektifan waktu dapat diperoleh dengan perbandingan Waktu standart (Ws) alat baru sebesar 23,56 menit dan untuk alat lama Waktu standart (Ws) sebesar 487,13 atau 8,11 jam dan output standart (Os) alat baru sebesar 2,1 kg / jam sedangkan output standart (Os) alat lama sebesar 0,102 kg / jam (Terjadi peningkatan sebesar 95,14 \%)

\section{DAFTAR PUSTAKA :}

Wignjosoebroto, Sritomo. 2003, Ergonomi Study Gerak dan Waktu. Guna Widya Surabaya.

Ulrich, Karl T. and Steven D, Eppinger. 2001. Perancangan dan Pengembangan Produk. Jakarta: Salemba Teknik.

Widodo, Imam Djati, 2005, Perencanaan dan Pengembangan Produk, UII Press, Yogyakarta. 